\title{
Changes in otter numbers in Shetland between 1988 and 1993
}

\author{
Jim Conroy and Hans Kruuk
}

The otter population in Shetland has increased significantly between 1988 and 1993, with more animals being found on all coastal strata and in all parts of the archipelago except South Mainland, the only area to show a decline. South Mainland is where the tanker Braer grounded in January 1993 and the subsequent oil spill might have affected the distribution of otters there. The causes of the changes are unknown and it is not known what happened to the otters in South Mainland after the spill, but it is is highly unlikely that the large increases recorded elsewhere on the archipelago were caused by the movement of animals away from South Mainland.

\section{Introduction}

Throughout much of their European range, the numbers of Eurasian otters Lutra lutra have declined dramatically during the past four decades (Macdonald and Mason, 1990) with concern being expressed about the survival of the species in many areas. One of the species's strongholds is Scotland, in particular the Highlands and Islands (Green and Green, 1980, 1987), with the population on Shetland being of national and international importance (Kruuk et al., 1989). In Shetland otters live on the coasts and feed mainly in the sea.

On two occasions recently the Shetland otter population was believed to be seriously at risk from a sudden environmental hazard. On both occasions the whole population was surveyed using a sampling technique (Kruuk et al., 1989) that provided an opportunity to assess population changes over a 5-year period.

In 1988 an epidemic among seals in the North Sea was initially thought to be caused by the canine distemper virus (Osterhaus and Vedder, 1988), to which otters were known to be susceptible (Duplaix-Hall, 1975). Otters in Shetland come into contact with common seals Phoca vitulina and were therefore at risk. In order to assess the possible impact of the disease, it was important to determine the status and distribution of the local otter population.
These data could then form the basis for any subsequent monitoring. This led to the first estimate of the Shetland otter population (in fact the first detailed estimate of a population of this species anywhere; Kruuk et al., 1989).

On 5 January 1993 the tanker Braer grounded on the rocks at Garths Ness on South Mainland, Shetland (Figure 1; Wills and Warner, 1993). Over the following days the Braer lost 84,000 tonnes of crude oil, twice the volume lost by the Exxon Valdez in Alaska in 1989, and, with the additional fuel and diesel oil, there was the potential for a major ecological disaster (Bayfield and Conroy, 1994). Included among the species likely to be at risk were otters, which are known to suffer badly if they become contaminated by oil (Bayha and Kormendy, 1990; Conroy, 1995). It was decided, therefore, to assess the affect of this oil spill on the local population of otters.

\section{Methods}

A major problem in the study of otter ecology has been the difficulty in finding a method that allows the number of animals to be assessed accurately. Most studies have been based on the use of otter signs, in particular their faeces (spraints). While this may give an index of otter distribution, the methodology is 


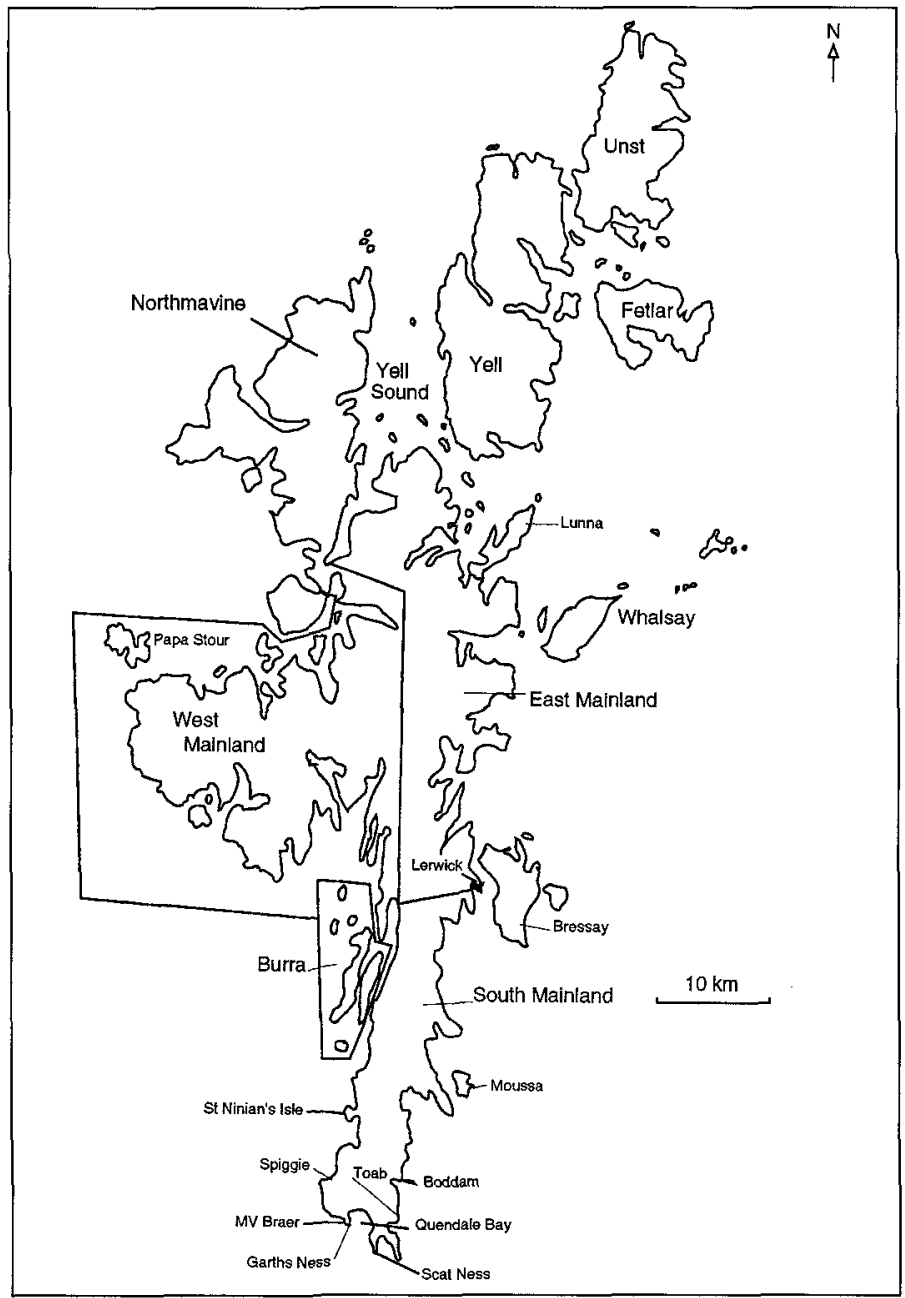

Figure 1. Shetland, showing the geographic areas and places mentioned in the text. fraught with problems, particularly the very large seasonal variation in spraint deposition (Conroy and French, 1985, 1987; Kruuk et al., 1986; Kruuk and Conroy, 1987). The results from such surveys, therefore, cannot be used to determine subsequent numerical changes in the population.

Quantitative information is needed to monitor successfully changes in otter numbers and distribution and to establish valid baseline data. During studies on the otters at Lunna, Shetland (Figure 1), Moorhouse (1988) found a significant correlation between the numbers of adult females and occupied holts (dens). From this correlation and the ratio of males to females in the population, it became possible to estimate the number of otters in Shetland and so establish a valid database.

The methods used for the 1993 survey and the assumptions made have been described in detail elsewhere (Kruuk et al., 1989) and are summarized below.

\section{Census of holts}

A holt was defined as a tunnel system with signs of regular use by otters - evidence included spraints, tracks and the characteristic smooth wear at entrances. (For this study piles of rocks were excluded.) Holts were estimated along a strip of coast $100 \mathrm{~m}$ wide.

The coastline of Shetland (Figure 1) was 
Table 1. The coastal strata used in the otter census of Shetland and the number of $5-\mathrm{km}$ sections in each stratum

\begin{tabular}{llccc}
\hline & & \multicolumn{3}{l}{ No of sections } \\
\cline { 4 - 5 } Coastal & & \multicolumn{3}{c}{ Surveyed } \\
\cline { 4 - 5 } type & Description of stratum & In stratum & 1988 & 1993 \\
\hline I & Steep cliffs - over 10 m high & 89 & 20 & 28 \\
II & Agriculture - 'improved' land & 61 & 21 & 24 \\
III & Not I or II - peat (almost all pasture) & 40 & 22 & 24 \\
IV & Not I or II - non peat & 47 & 21 & 24 \\
V & Built up areas & 5 & 0 & 0 \\
VI & Small islands & $(133)^{\star}$ & $(47)^{\star}$ & $(62.5)^{\star}$ \\
\hline
\end{tabular}

${ }^{*}$ numbers in parentheses are distances in $\mathrm{km}$.

divided into $2425-\mathrm{km}$ sections; in addition, 38 small islands (133 km of coastline) were considered in the survey. Each $5-\mathrm{km}$ section was allocated to one of six strata identified from previous reports (Milner, 1978; Gammack and Richardson, 1980), maps and our knowledge of the area (Table 1). The island were also divided into nine areas (Table 2).

The sections to be surveyed were chosen randomly, but with more intensive sampling in those strata where most otter holts were expected. Five kilometres was chosen as the sample length because that distance corresponded approximately to the length of coast used by a resident female as a home range.

Each section was surveyed by an experienced observer during September/October in both 1988 and 1993 (two surveyors were involved in both surveys). Searching for holts involved walking along the coast zig-zagging and inspecting all likely holt sites.

\section{Relationship between number of otters and holts}

Independent observations on the number of individual otters and a knowledge of the distribution and use of holts in the detailed study area at Lunna established a significant correlation between the numbers of female otters and the number of occupied holts. We also knew the relationship between the proportion of males to females in the population. These are described fully in Kruuk et al. (1989). To arrive at an estimate of the total population, it is necessary to multiply the number of females by 1.83 .
Table 2. The geographical boundaries of Shetland used in the otter census, the number of 5$\mathrm{km}$ sections in each section and the number surveyed in 1988 and 1993

\begin{tabular}{lccc}
\hline & \multicolumn{3}{c}{ No of 5-km sections } \\
\cline { 2 - 4 } Location & In area & \multicolumn{2}{c}{ Surveyed in } \\
\cline { 3 - 4 } Unst & 19 & 6 & 1993 \\
Fetlar & 9 & 3 & 6 \\
Yell & 28 & 11 & 3 \\
East Mainland & 54 & 18 & 12 \\
South Mainland & 26 & 9 & 17 \\
West Mainland & 62 & 24 & 25 \\
Northmavine & 34 & 9 & 11 \\
Burra & 10 & 4 & 7 \\
Small islands & $(38)^{\star}$ & $(12)^{\star}$ & $(15)^{\star}$ \\
Total (excluding small islands) & 242 & 84 & 100 \\
\hline
\end{tabular}

* figures in parentheses are of small islands surveyed. 
Table 3. The number of holts estimated for each stratum in 1988 and 1993

\begin{tabular}{|c|c|c|c|c|c|c|c|c|}
\hline \multirow[b]{2}{*}{ Stratum } & \multicolumn{4}{|l|}{1988} & \multicolumn{4}{|l|}{1993} \\
\hline & $\begin{array}{l}\text { Estimated } \\
\text { no. holts }\end{array}$ & $\begin{array}{l}\text { Population } \\
\text { variance }\end{array}$ & $S E$ & $\begin{array}{l}95 \% \\
\text { confidence } \\
\text { limits } \\
(\%)\end{array}$ & $\begin{array}{l}\text { Estimated } \\
\text { no. holts }\end{array}$ & $\begin{array}{l}\text { Population } \\
\text { variance }\end{array}$ & SE & $\begin{array}{l}95 \% \\
\text { confidence } \\
\text { limits } \\
(\%)\end{array}$ \\
\hline I Cliff & 159.3 & 1753.3 & 41.9 & $\pm 82.1(51)$ & 148.6 & 659.7 & 25.7 & $\pm 50.4(36)$ \\
\hline II Agriculture & 101.9 & 700.9 & 26.5 & $\pm 51.9(51)$ & 195.7 & 988.4 & 31.4 & $\pm 61.6(31.5)$ \\
\hline III Peat & 530.9 & 1923.7 & 43.9 & $\pm 86.0(17)$ & 561.2 & 1696.3 & 41.2 & $\pm 80.7(14)$ \\
\hline IV Other & 192.5 & 907.2 & 30.1 & $\pm 59.0(31)$ & 1188.0 & 820.9 & 28.7 & $\pm 56.2(28.9)$ \\
\hline V Buildings & - & - & - & - & - & - & - & - \\
\hline $\begin{array}{l}\text { VI Small } \\
\text { islands }\end{array}$ & 206.6 & 833.9 & 28.9 & $\pm 56.6(12)$ & 288.1 & 977.4 & 31.3 & $\pm 61.3(21.3)$ \\
\hline All & 1191.2 & 6119.0 & 78.2 & $\pm 153.3(13)$ & 1381.6 & 5142.7 & 71.7 & $\pm 140.6(10.2)$ \\
\hline
\end{tabular}

\section{Results}

\section{8 survey}

A total of $845-\mathrm{km}$ sections was surveyed and a sample of 445 holts counted; in addition, 73 holts were found on the 12 small islands visited. The number of holts counted in and the estimated total for each stratum is shown in Table 3. A total of 1191 holts was calculated (with 95\% confidence limits of 13\%). There was great variance between and within strata, with the difference between the strata being highly significant ( $F=28.79 ; P=0.001)$.

The densities of holts on the small islands and Mainland areas were also different, with most holts being found in East Mainland and least on South Mainland, where in the largely agricultural area and cliff coasts, the low density was especially conspicuous (Table 4, Figure 1). The presence of otter holts was also strongly associated with the presence of fresh water (61 per cent of sections with holts also contained freshwater pools).

From that survey, we concluded that the distribution of otter holts in Shetland was closely related to the availability of peat and freshwater, fewest holts were found on cliff coasts.

The otter population was estimated as 718 adults. Taking into account the various potential errors in the methodology and assumptions, it was confidently estimated that the population on Shetland was between 700 and 900 animals. This indicated that there were $0.5-0.7$ individuals per $\mathrm{km}$ of coast, a figure similar to that from a previous estimate of 0.8 individuals per $\mathrm{km}$ from Fetlar (Baker et al., 1981).

\section{3 survey}

Because one of the aims of this survey was to determine the possible effects of the Braer oil spill on the otter population, it was decided to increase the number of sections to be surveyed, particularly in South Mainland, the area where the tanker grounded (Conroy and Kruuk, 1994).

In this instance $1005-\mathrm{km}$ sections $(500 \mathrm{~km}$ of coastline) and 15 islands $(62.5 \mathrm{~km})$ were surveyed (Tables 1 and 2). A total of 557 holts was counted in the $5-\mathrm{km}$ sections with a further 130 holts on the small islands (Table 3). The increase in the sections visited in both 1988 and 1993 was 101 holts (67 in the $5-\mathrm{km}$ sections; 34 from the small islands) - an increase of 14.7 per cent. The overall estimate for the number of holts in 1993 was 1380 (with $95 \%$ confidence limits of $10.2 \%$ ), an overall increase of 189 holts (15.2 per cent) from the 1988 estimate (Table 3 ). The difference in the number of holts counted in the two surveys was significant $(z=-2.99 ; P=0.0028$, Wilcoxon paired test).

The main increase (94 holts) was in the 


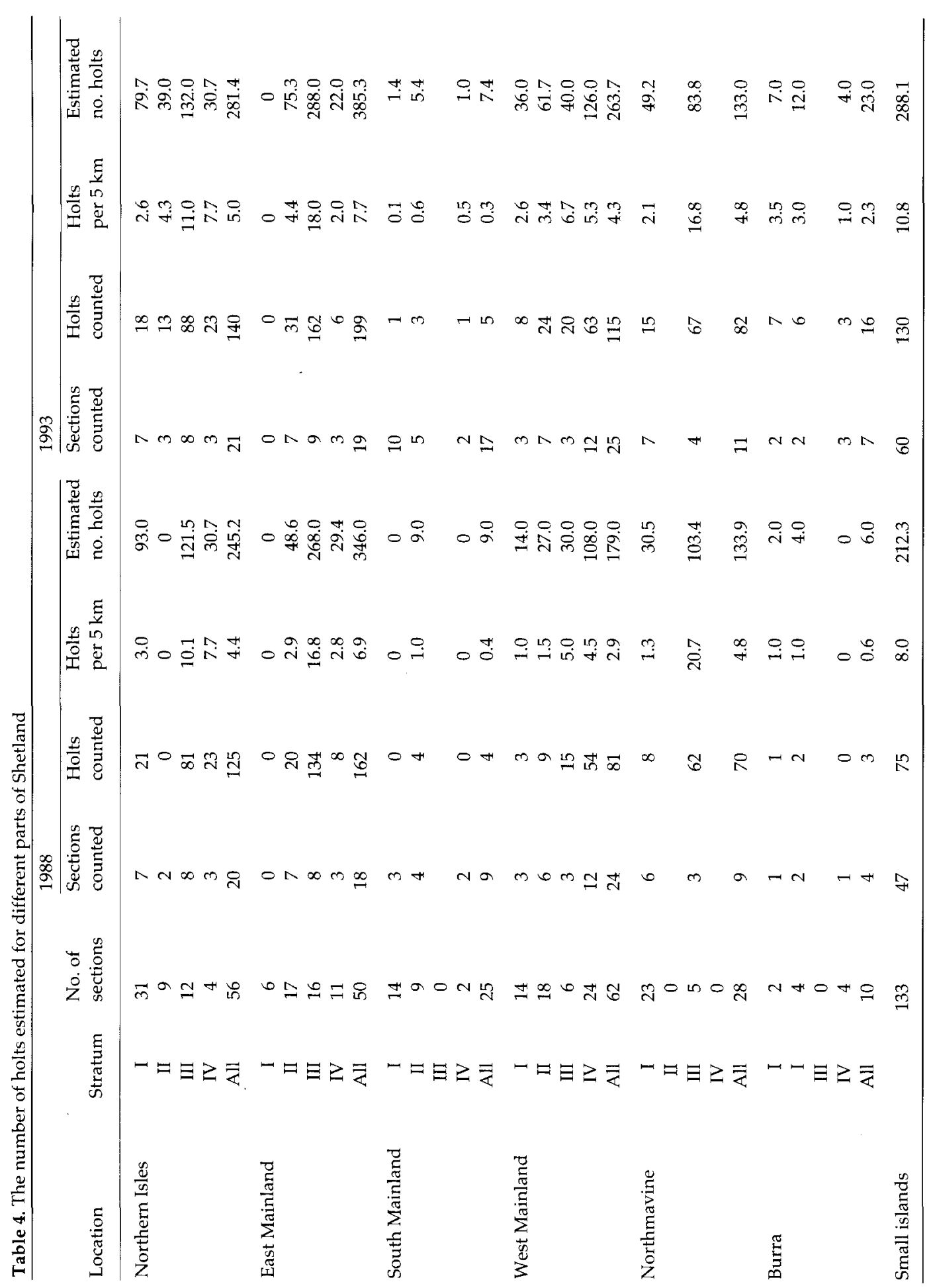


number of holts found on agricultural land, where the density per $5-\mathrm{km}$ section increased from 1.57 to 3.21 .

When the different parts of the islands were compared (Table 4), there were increases in all areas except South Mainland, where there was a decline in the number of occupied holts. The largest increase was in West Mainland, where an additional 88 holts were estimated.

The number of otters on Shetland was estimated as 836, an increase of 118 (16.4 per cent). Again accepting the potential errors mentioned for the 1988 survey, we estimated that the adult otter population on Shetland in 1993 was between 800 and 1050 individuals.

\section{Discussion}

The 1993 study was based on a survey of 100m-wide strip along 41 per cent of the Shetland coastline. The calculation of 1380 holts, giving an otter population of 836 adult animals, was based on several assumptions. These are discussed fully in Kruuk et al. (1989). From a detailed knowledge of otters in Shetland, it was felt that these assumptions were reasonably well met.

Over the past 5 years, there has been a significant increase in the estimated number of otters in Shetland. This increase was found in all strata except cliff, and in all areas except South Mainland. The overall density of holts per $5-\mathrm{km}$ section increased from 5.61 to 6.13 , with the greatest increase in agricultural land (1.57 to 3.21). The apparent decline in the use of holts in the cliff stratum may not be real, but caused by having increased the number of sections in this stratum surveyed in 1993, the majority, eight from nine, being located in South Mainland. These extra sections were chosen to increase the representation of South Mainland in the current survey. This part of Shetland, however, is known to have the poorest otter density in Shetland. If the analysis of cliff stratum is restricted only to those sections surveyed in both 1988 and 1993, there is in fact an increase in the density of otter holts, from 1.79 to 2.15 per $5 \mathrm{~km}$. This would gave an increase of 42 holts in the cliff stratum as opposed to a decrease of 19 as reported using the additional sections.

In Shetland the majority of otter cubs are born during the early summer. There is a strong correlation between the amount of food available to otters in July / August and the subsequent recruitment of cubs to the population (Kruuk et al., 1987; Kruuk and Conroy, 1991). Also, during late winter, otters have difficulty in catching food [prey populations inshore being at their lowest levels (Kruuk et al., 1988)], non-violent (natural) mortality is highest, and animals are in their poorest condition (Kruuk et al., 1987, 1991). Changes in fish populations can therefore affect otter numbers. Fish numbers are known to fluctuate from year to year and do not appear to show any regular trend (Kruuk et al., 1988). The two otter surveys could well have taken place at times of differing fish populations, the 1988 at a low level and/or 1993 at a high. Before we can say effectively whether or not there is an increasing trend in the population it will be necessary to undertake other surveys at regular intervals. For example, the fish population at Lunna in the summer of 1993 was the lowest recorded in 6 years of data collection; cub production was also at its lowest, only two young being seen (Conroy and Kruuk, 1994). How will this affect otter numbers in the future?

There appears to have been a decrease in otter activity in South Mainland and the obvious question arose: could this be associated with the Braer oil spill? Immediately after the grounding the otter situation was constantly monitored. The results of this have been described in detail elsewhere (Conroy et al., 1994; Conroy, 1995). However, below is a summary of the findings made in the 2 weeks immediately after the spill, in the area between Boddam and St Ninian's Isle (Figure 1).

- Six otters were found dead. Although one was only slightly oiled, it was in very poor condition and it is unlikely it would have survived even if it had not been contaminated. No other deaths could be directly associated with the Braer incident.

- There were at least 20 sightings of otters (some probably the same individual being 
seen on more than one occasion).

- Nine holts were in use, including two found during the 1988 survey and one, at a small hole, immediately above the wreck.

- Between 20 and 25 spraint sites were found, many containing fresh spraints.

During January 1993, there was otter activity on South Mainland in the area around the grounded tanker. Because of the high winds and heavy rain, many spraint sites were washed out, so the figures listed above for holt occupancy and spraint sites in use must be seen as a minimum.

The September 1993 survey found no occupied holts in the area from Scat Ness to St Ninians Isle (25 km of coast) (Figure 1). In addition, no spraints were found and no animals seen. In November 1993, spraints were found on the east side of Quendale Bay and at the entrance to Loch of Spiggie (Figure 1), but still no holts were found to be in use.

During the summer, the number of spraints found on the coast is at a minimum (Conroy and French, 1985, 1987). Despite this, the total absence of any evidence of otter presence in the $25 \mathrm{~km}$ around Braer, including the lack of use of the holts found occupied in 1988, the continuing situation in November and the increase in the number of holts in use elsewhere on the islands, suggest strongly that there has been a decrease in otter activity on South Mainland. Whether the few otters that would have been expected to be there had died or moved away is not known. Their disappearance, however, cannot account for the increase in the otter population elsewhere in Shetland, because the additional numbers involved are too great. It should also be pointed out that fish traps set in Quendale Bay during June and August 1993 failed to catch any bottomliving fish [the species upon which otters primarily feed (Kruuk et al., 1988)]. In February 1994 two shore rockling Gaidropsarus mediterraneus were caught in Quendale Bay, while in March, otters were again in the area - prints being found on the beach at Quendale (M. Heubeck, pers. comm.).

Studies of the levels of polyaromatic hydrocarbons in bottom-living species of fish collected around Shetland found elevated levels at sites within the area affected by oil from the spill, (St Ninian's Isle and Burra) during April and June 1993, 6 months after the grounding. No such levels were found at control sites (Lunna and Voe). By August, levels at the contaminated sites had dropped to background level (Conroy and George, 1993).

\section{Acknowledgements}

We are grateful to A. Moorhouse, P. Chanin, E Bacon, R. Gallagher, T. Holmes and staff from Scottish Natural Heritage (SNH; Lerwick office), for their valuable assistance in the field. For use of boats to reach some of the smaller islands we are indebted to BP, SNH and R. Tulloch. The manuscript was read by Professor B. W. Staines, whose comments were very much appreciated. The original survey was part funded by World Wide Fund for Nature (WWF-UK) through the Heinz Guardians of the Countryside Campaign. The 1993 survey was funded in part through the Ecological Steering Group on the Oil Spill in Shetland (with monies from Department of Environment, European Union and $\mathrm{SNH}$ ), Greenpeace Environmental Trust and WWF-UK. To these organizations we offer our thanks. We are also grateful to Shetland Oil Terminal Environmental Advisory Group for its continued interest in the otter project.

\section{References}

Baker, J.R., Jones, A.M., Jones, T.P. and Watson, H.C. 1981. Otter Lutra lutra L. mortality and marine oil pollution. Biological Conservation, 20, 311-332.

Bayfield, N.G. and Conroy, J.W.H. 1994. Ecological aspects of the Braer oil spill in Shetland: a case study. Indo-British Workshop on Environmental Impact and Risk Assessment of Petrochemical Industry and Environmental Audit, 8-10 January 1994. 105-111. NEERI, Nagpur, India.

Bayha, K. and Kormendy, J. (eds). 1990. Sea otter symposium: Proceedings of a symposium to evaluate the response effort on behalf of sea otters after the T/V Exxon Valdez oil spill in Prince William Sound, Anchorage, Alaska, 17-19 April 1990. US Fish \& Wildl. Serv. Biol. Rep. 90, (12). 485 pp.

Conroy, J.W.H. 1995. Otters and oil spills - the impacts and the effects. Cahiers d'Ethologie.

Conroy, J.W.H. and French, D.D. 1985. Monitoring Otters in Shetland. Report to Shetland Oil Terminal Environmental Advisory Group, Aberdeen. Institute of Terrestrial Ecology, Banchory. 
Conroy, J.W.H. and French, D.D. 1987. The use of spraints to monitor populations of otters (Lutra lutra). Symp. Zool. Soc., Lond. 58, 247-262.

Conroy, J.W.H. and George, S.E. 1993. Otters in Shetland: Monitoring the Impact of the Braer Oil Spill. 1. Petroleum Hydrocarbons in Inshore Fish. Institute of Terrestrial Ecology, Banchory.

Conroy, J.W.H. and Kruuk, H. 1994. Otters in Shetland: Monitoring the impact of the Braer Oil Spill. 2. A Census of Otter Numbers. Institute of Terrestrial Ecology, Banchory.

Conroy, J.W.H., Kruuk, H. and George, S.E. 1994. Otters in Shetland: Monitoring the Impact of the Braer Oil Spill. Final report. Institute of Terrestrial Ecology, Banchory.

Duplaix-Hall, N. 1975. River otters in captivity: a review. In Breeding Endangered Species in Captivity (ed. R. D. Martin), pp. 315-327. Academic Press, London.

Gammack, J.J.M. and Richardson, M.G. 1980. A Compendium of Ecological and Physical Information on the Shetland Coastline. Nature Conservancy Council, Lerwick.

Green, J. and Green, R. 1980. Otter Survey of Scotland 1977-79. Vincent Wildlife Trust, London.

Green, J. and Green, R. 1987. Otter Survey of Scotland 1984-85. Vincent Wildlife Trust, London.

Kruuk, H. and Conroy, J.W.H. 1987. Surveying otter Lutra lutra populations: a discussion of problems with spraints. Biological Conservation, 41, 179-183.

Kruuk, H. and Conroy, J.W.H. 1991. Mortality of otters Lutra lutra in Shetland. J. app. Ecol. 28, 95-101.

Kruuk, H., Conroy, J.W.H., Glimmerveen, V. and Ouwerkerk, E.J. 1986. The use of spraints to survey otters Lutra lutra. Biological Conservation, 35, 187-194.

Kruuk, H., Conroy, J.W.H. and Moorhouse, A. 1987.
Seasonal reproduction, mortality and food of otters (Lutra lutra L.) in Shetland. Symp. Zool. Soc., Lond. 58, 263-278.

Kruuk, H., Conroy, J.W.H. and Moorhouse, A. 1991. Recruitment to a population of otters (Lutra lutra) in Shetland in relation to food. J. app. Ecol. 28, 95-101.

Kruuk, H., Moorhouse, A., Conroy, J.W.H., Durbin, L. and Frears, S. 1989. An estimate of numbers and habitat preferences of otters Lutra lutra in Shetland, UK. Biological Conservation, 49, 241-254.

Kruuk, H., Nolet, B. and French D.D. 1988. Fluctuations in numbers and activity of inshore demersal fishes in Shetland. J. Mar. Biol. Ass. UK, 68, 601-617.

Macdonald, S.M. and Mason, C.F. 1990. Action plan for European otters. In Otters: An Action Plan for their Conservation (eds P. Foster-Turley, S. Macdonald, and C. Mason), pp. 29-40. IUCN, Gland, Switzerland.

Milner, C. 1978. Shetland ecological survey. Geogr. Mag. 50, 730-753.

Moorhouse, A. 1988. Distribution of holts and their utilisation by the European otter (Lutra lutra) in a marine environment. MSc thesis, University of Aberdeen, Aberdeen.

Osterhaus, A.D.M. and Vedder, E.J. 1988. Identification of virus causing recent seal deaths. Nature, Lond., 335, 20.

Wills, J. and Warner, K. 1993. Innocent Passage: The Wreck of the Tanker Braer. Mainstream Publishing, Edinburgh and London.

Jim Conroy and Hans Kruuk, Institute of Terrestrial Ecology, Banchory Research Station, Glassel, Banchory, Kincardineshire AB31 4BY, UK. 